Dorota Tomczyszyn ${ }^{1}$

ORIGINAL PAPER

Leszek Solecki ${ }^{2}$

Anna Pańczuk ${ }^{3}$

\title{
ASSESSMENT OF THE TYPE OF FARMERS' LOW BACK PAIN
}

Pope John Paul II State School of Higher Education in Biała Podlaska, Biała Podlaska, Poland

${ }^{1}$ Department of Sociology

${ }^{2}$ Department of Public Health

${ }^{3}$ Department of Physiotherapy

\begin{abstract}
Background: Spinal overload among blue-collar workers occurs most frequently in the lumbar spine. Long-lasting spinal overload results in pain syndromes leading to limitations in everyday and professional life. Material and Methods: The research included 106 adult males working as farmers for at least 10 years. The control group included 50 male white-collar workers. Four research tools were used: an interview questionnaire, a questionnaire assessing pain intensity and limitations in everyday functioning of study participants, a Numeric Rating Scale (NRS) measuring pain intensity and Oswestry Disability Index. Results: The research revealed that as many as $86 \%$ of the farmers (91 individuals) experienced low back pain. In the control group only $64 \%$ of all the white-collar workers complained of pain in this part of the spine. The farmers defined their low back pain as constant pain or stiffness significantly more often. In addition, they reported hip pain radiating to one or 2 legs and experienced chronic and acute back pain more frequently. The total time in which they experienced this pain was usually 11-20 years. The correlation between pain intensity measured on a numeric scale and the level of disability of farmers was revealed. Conclusions: The research revealed that individual farmers complained of low back pain significantly more often. The pain was usually defined as constant pain, chronic pain, acute pain or hip pain radiating to legs. Med Pr 2018;69(4):355-364
\end{abstract}

Key words: disability, research, work, back pain, pain intensity, individual farmers

Corresponding author: Dorota Tomczyszyn, Pope John Paul II State School of Higher Education in Biała Podlaska,

Department of Sociology, Sidorska 95/97, 21-500 Biała Podlaska, Poland, e-mail: tomczyszyn@o2.pl

Received: September 5, 2017, accepted: December 19, 2017

\section{INTRODUCTION}

Spinal overload among blue-collar workers usually occurs in the lumbar spine [1]. Long-lasting spinal overload results in pain syndromes leading to limitations in everyday and professional life. Spine disorders are the most commonly reported health problems connected with a farmer's work.

Despite the fact that farmers perform their duties in a natural environment, they are exposed to numerous harmful factors. One of them is low back overload. Injuries in this part of the spine prevent workers from working efficiently and for a long time. Long-lasting work in a non-ergonomic, asymmetric position while driving tractors and other self-propelled agricultural machines as well as using the same groups of muscles lead to the loss of neuro-muscular balance and it results in back pain [1]. Previous studies confirm the existence of these disorders and their medical, social and economic consequences $[1,2]$. It is highlighted that even individuals possessing knowledge of the prophylaxis and protection of the spine do not put it into practice in physical and professional work [2]. Low back pain frequency among farmers, the costs of rehabilitation, long-lasting treatment and ineffectiveness of prophylactic programs bring about the need for taking up research aimed at a deep analysis of the problem and its resultant limitations and disabilities occurring in everyday functioning of the farmers.

Although injuries of the lumbar spine are common in all branches of industry and in all professions, numerous studies have shown that they are particularly common in certain jobs and industry sectors. Particularly high occurrence indices are noted in such professional groups as farmers, construction workers, carpenters, drivers (including truck and tractor drivers), nurses, cleaners, etc.

In their studies, scientists from Sweden [3], Nigeria [4], Brazil [5] and the USA [6-11] reported that low back pain and musculoskeletal disorder symptoms occurred among farmers.

Previous research conducted by various authors seems to indicate that factors causing low back pain include whole-body vibration, physical work, lift- 
ing heavy loads and an uncomfortable working position $[3,6-8,10]$.

\section{Objective}

The objective of the work was to define the type and intensity of low back pain and the level of disability among individual farmers working at their family farms.

\section{MATERIAL AND METHODS}

The research included 106 adult males working as farmers for at least 10 years. Their mean age was $46.6 \pm 10.4$ years (range: $27-78$ years), while their work experience (with exposure to whole body vibration and overload caused by strenuous physical exertion) was $25.3 \pm 10.3$ years. Almost a half of the farmers participated in vocational training courses organized by the Agricultural Advisory Centers (47\%). While selecting the research sample it was also assumed that being a farmer had to be the only job that they performed. They worked in mixed crop-livestock farming. On average, they possessed $28.8 \pm 20.6$ ha of land (range: $10-100 \mathrm{ha}$ ), so they met the criterion of cultivating the land that covered the area of at least 10 ha.

The farms run by the study participants had basic technical facilities indispensable for agricultural produce, including tractors, agricultural machines conjugated with tractors and self-propelled agricultural machines that were operated by the examined males. Moreover, machines for producing animal feed and repair tools were used on the farms.

In crop produce, farmers work an average of $8 \mathrm{~h}$ daily in the summer; however, this group also included individuals who worked even up to $14 \mathrm{~h} /$ day. During the summer farmers spend an average of $3 \mathrm{~h}$ daily lifting or carrying heavy loads. In spring and autumn, it is $6 \mathrm{~h}$ of work per day, including $2 \mathrm{~h}$ of lifting heavy loads. When driving a tractor, farmers usually work in a sitting position with an upper part of the body rotated to the back in order to observe work done behind the tractor. Eighty-nine farmers, who constituted $84 \%$ of the group, reported such situations.

The farmers also prepared feed for the livestock. Most commonly, they devoted 1-2 h/day to these activities (31-37\% of the farmers). While preparing animal feed, they spent some time lifting and carrying heavy loads. According to over a half of the study participants (54\%), it took $1 \mathrm{~h} /$ day; $25 \%$ claimed it was $2 \mathrm{~h}$, while the remaining farmers devoted more than $3 \mathrm{~h}$ to this activity (12\%). Feeding animals is another everyday duty on a farm connected with carrying heavy loads. Average time devoted to these activities by 1 farmer was $1.7 \mathrm{~h}$, while lifting heavy loads took $1.2 \mathrm{~h}$ daily.

Average time devoted to manual loading was $1.3 \mathrm{~h} /$ day in winter and over $3 \mathrm{~h} /$ day in summer. During this activity, farmers carried an average of $15 \mathrm{~kg}$ daily in winter, while in spring it was $31 \mathrm{~kg} /$ day. They usually claimed that their work on a farm was hard (52\% of the respondents) or moderate (34\%).

Nearly a half of the group participated in various specialist training courses (50 individuals, i.e., 47\%). These were usually qualification courses in the field of agriculture, e.g., combine-harvester driving, the use of chemical fertilizers, dairy cows breeding or even agriculture university studies.

The control group included 50 males (white-collar workers) from the same age group (aged $42.2 \pm 11.3$ years, range: $26-73$ years). They spent the majority of their working day in a sitting position (a maximum of $28 \%$ for $5-6 \mathrm{~h}, 22 \%$ for $7-8 \mathrm{~h}, 20 \%$ for $3-4 \mathrm{~h}$ and $16 \%$ for over $8 \mathrm{~h}$ ). In both groups only males were examined at the same time and in the same area. No statistical differences concerning age between the group of farmers and the control group were noted ( $p=0.0728)$, which justified making comparisons between these groups.

The research was conducted in the northern part of the Lublin Province in the years 2014 and 2015.

In the research, the following 3 research tools were applied:

1. Interview questionnaire.

2. Numeric Rating Scale (NRS) for measuring pain intensity.

3. Oswestry Disability Index (ODI).

Research tool No. 1 is an interview questionnaire based on the Nordic Questionnaire [12]. Questions formulated in this questionnaire regarded, inter alia, the occurrence (or not) of pain, the period in which pain was experienced, types of pain (constant pain, shortterm pain, acute pain, chronic pain, pain radiating to 1 or 2 legs), the duration of the disorder (throughout professional life) divided into particular stages, hospital stays caused by these disorders, disc herniation, changes of work caused by back pain, occurrence of pain depending on the time of day as well as periods without pain and the frequency of specialist visits.

Research tool No. 2 is a standardized method of pain assessment known in literature as the Numeric Rating Scale. According to this method, a participant independently and subjectively defines pain intensity 
on the scale from 0 to 10 pts ("no pain" - 0 pt, "very strong pain" - $10 \mathrm{pts})$. The selected value on the scale defines pain intensity.

Research tool No. 3 assesses the level of disability of farmers caused by low back pain. It is called the Oswestry Disability Index (ODI). This questionnaire is divided into 10 sections, i.e., pain intensity, personal care, lifting, walking, sitting, standing, sleeping, sex life, social life and traveling. In each domain the subject can choose one out of 6 graded variants. Each variant is assessed on the scale of $0-5$ pts, while the final assessment is calculated according to the formula:

$$
\text { Sum of points } / 50 \times 100 \%=\% \text { of the disability }
$$

The following levels of disability were established: 0-20\% - no or minimal disability; $21-40 \%$ - moderate disability; $41-60 \%$ - serious/big disability; $61-80 \%$ severe disability/invalidity and $81-100 \%$ - total invalidity (such patients are either bedridden or exaggerate their problems).

To assess the significance of differences between the groups (farmers vs. control group), a non-parametric Pearson's $\mathrm{Chi}^{2}$ test was applied. Statistical significance was accepted at the level of $p<0.05$. The correlation between intensity of the pain on a point scale and the degree of disability of farmers was analyzed by means of a correlation index.

\section{RESULTS}

\section{Low back (lumbar spine) pain}

among farmers and in the control group

The questionnaire revealed that from among $106 \mathrm{ex}-$ amined farmers, 15 respondents (14\%) did not report any low back pain. The remaining 91 farmers (86\%) experienced low back pain. This type of pain is less common among white-collar workers (control group), where 32 respondents (64\%) suffered from it. The difference between these research groups is statistically significant $(p=0.002)$. The next part of the research included respondents reporting low back pain (91 farmers and 32 white-collar workers).

The analysis of pain frequency in relation to the duration of the disorder (the whole professional life, the last 12 months, or the last 7 days) revealed (Figure 1) that over a half $(53.9 \%, \mathrm{~N}=49)$ of the farmers had suffered from pain within the last 12 months, $35.2 \%$ $(\mathrm{N}=32)$ had experienced it throughout professional life, while every tenth farmer had felt pain within the last week $(11 \%, \mathrm{~N}=10)$. The comparison of the results of the farmers with the control group showed that in the control group the pain occurring throughout life was reported less frequently $(15.6 \%, \mathrm{~N}=5)$, while pain occurring within the last week was declared more frequently $(28.1 \%, \mathrm{~N}=9)$. The difference of data between the 2 groups is statistically significant $(\mathrm{p}=0.02)$.

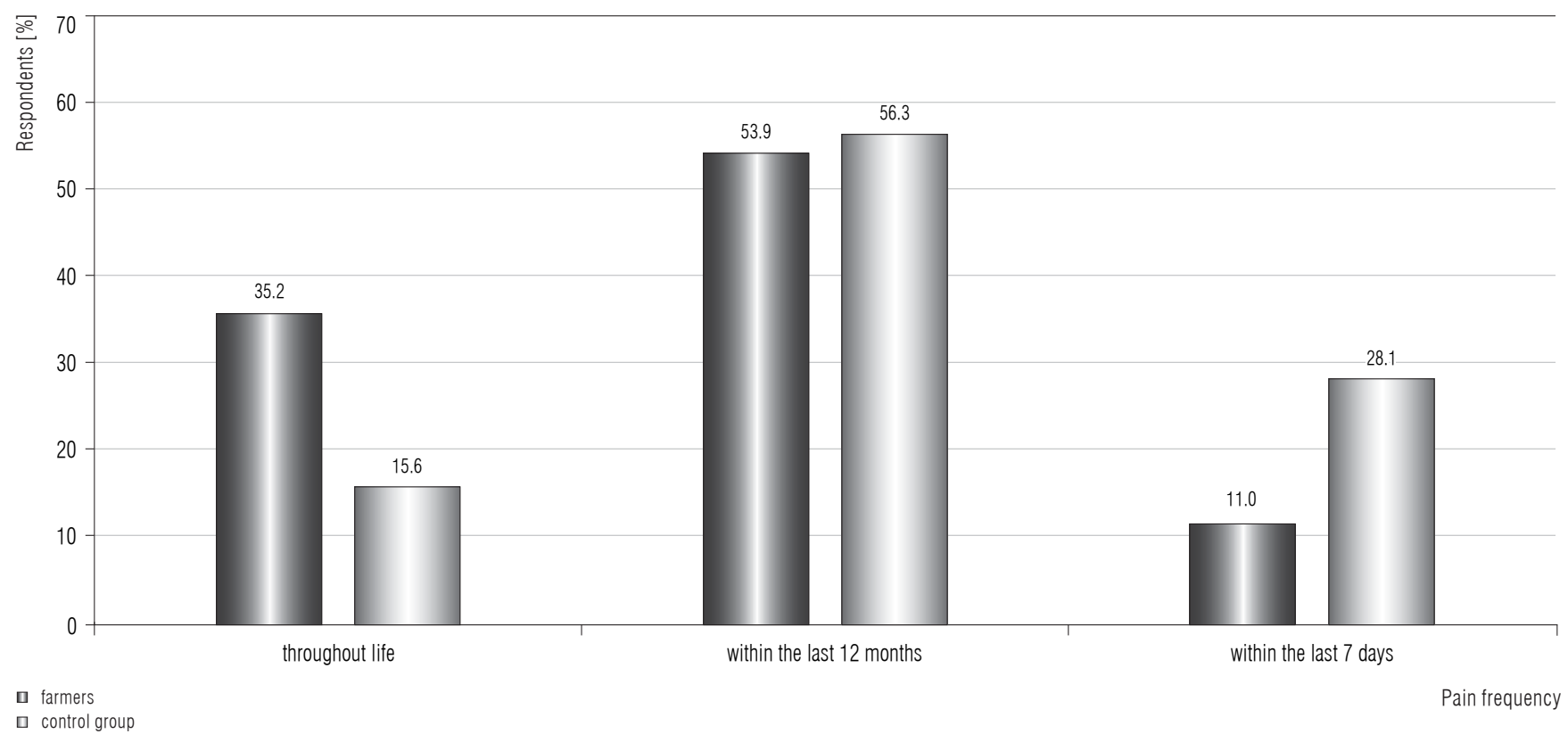

Fig. 1. Pain frequency in relation to the duration of the disorder - males working $\geq 10$ years as farmers $(\mathrm{N}=106)$ vs. male white-collar workers (control group, $\mathrm{N}=50$ ) 
Table 1. Occurrence of low back pain among males working $\geq 10$ years as farmers vs. male white-collar workers (control group)

\begin{tabular}{|c|c|c|c|c|c|}
\hline \multirow{3}{*}{$\begin{array}{l}\text { Interview questions } \\
\quad \text { (type of pain) }\end{array}$} & \multicolumn{4}{|c|}{$\begin{array}{l}\text { Respondents } \\
(\mathrm{N}=156)\end{array}$} & \multirow{3}{*}{$\mathrm{p}$} \\
\hline & \multicolumn{2}{|c|}{$\begin{array}{l}\text { farmers } \\
(\mathrm{N}=106)\end{array}$} & \multicolumn{2}{|c|}{$\begin{array}{l}\text { control group } \\
\quad(\mathrm{N}=50)\end{array}$} & \\
\hline & $\mathrm{n}$ & $\%$ & $\mathrm{n}$ & $\%$ & \\
\hline $\begin{array}{l}\text { Have you experienced low back pain, i.e., long-lasting pain or stiffness within } \\
\text { the last } 12 \text { months? }\end{array}$ & & & & & $\mathrm{p}<0.0001$ \\
\hline no & 21 & 23.1 & 22 & 68.8 & \\
\hline yes & 70 & 76.9 & 10 & 31.3 & \\
\hline $\begin{array}{l}\text { Have you experienced short-term pain ( }<14 \text { days) that could be relieved within } \\
\text { the last } 12 \text { months? }\end{array}$ & & & & & n.s. \\
\hline no & 34 & 37.4 & 25 & 78.1 & \\
\hline yes & 57 & 62.6 & 7 & 21.9 & \\
\hline $\begin{array}{l}\text { Have you experienced acute low back pain (sudden pain caused by an improper or rotated } \\
\text { back position) within the last } 12 \text { months? }\end{array}$ & & & & & $\mathrm{p}=0.0001$ \\
\hline no & 30 & 33.0 & 23 & 71.9 & \\
\hline yes & 61 & 67.0 & 9 & 28.1 & \\
\hline $\begin{array}{l}\text { Have you experienced chronic low back pain (occurring every day or in individual episodes } \\
\text { lasting longer than } 30 \text { days) within the last } 12 \text { months? }\end{array}$ & & & & & $\mathrm{p}=0.00016$ \\
\hline Does pain occurring during the day subside after rest? & & & & & n.s. \\
\hline no & 32 & 35.2 & 9 & 28.1 & \\
\hline yes & 59 & 64.8 & 23 & 71.9 & \\
\hline $\begin{array}{l}\text { Have you sought the help of a doctor, physiotherapist, chiropractor or any other specialist } \\
\text { because of low back pain within the last } 12 \text { months? }\end{array}$ & & & & & n.s. \\
\hline no & 53 & 58.2 & 18 & 56.3 & \\
\hline yes & 38 & 41.8 & 14 & 43.8 & \\
\hline $\begin{array}{l}\text { Have you undergone any treatment of low back pain (with the use of antiphlogistic drugs } \\
\text { or physiotherapy) within the last } 12 \text { months? }\end{array}$ & & & & & n.s. \\
\hline no & 51 & 56.0 & 22 & 68.8 & \\
\hline yes & 40 & 44.0 & 10 & 31.3 & \\
\hline Do you take any painkillers (without consulting the doctor) when strong pain occurs? & & & & & $\mathrm{p}=0.0002$ \\
\hline no & 26 & 28.6 & 21 & 65.6 & \\
\hline yes & 65 & 71.4 & 11 & 34.4 & \\
\hline
\end{tabular}

n.s. - not statistically significant. 
However, the frequency of occurrence of low back pain within the last 12 months was similar in both groups.

The analysis of the type of pain declared by the respondents (Table 1) revealed that pain reported by the farmers within the last year was more intensive as compared to the control group. Moreover, most differences between the groups were statistically significant. In comparison to the control group, farmers defined their low back pain as constant pain or stiffness more frequently (farmers - 76.9\%, control group - $31.3 \%$; statistically significant difference). Moreover, they more often felt hip pain radiating to 1 or 2 legs (62.6\% vs. $21.9 \%)$, experienced chronic pain (50.6\% vs. $12.5 \%)$ and complained about acute back pain (67\% vs. $28.1 \%)$. Cases of short-term pain that was relieved were more often reported in the group of farmers (farmers $-79.1 \%$, control group - $68.8 \%$; statistically insignificant difference).

Pain occurring in the morning and subsiding after some movement (Table 1) was reported by $68.6 \%$ of the farmers and $59.3 \%$ of the white-collar workers (statistically insignificant differences). After taking a rest during the day pain subsided more often in the control group (71.9\%) than among the farmers (64.8\%).

From spring to autumn $23.1-27.5 \%$ of the farmers experienced low back pain every day. In winter, such occurrences were less frequent (15.4\%). It also depended on the time of day - farmers felt pain more often in the morning and during the day than in the evening
(Figure 2). Respondents from the control group experienced pain more frequently in the morning and during the day as well. However, pain most often occurred after hard work (farmers - 39.6\%, control group - 50\%). The differences were not statistically significant.

Taking into account the duration of the disorder (in the whole professional life), it was concluded (Figure 3) that farmers most often experienced low back pain for $2-5$ years $(31.1 \%, \mathrm{~N}=28)$ and $11-20$ years $(30 \%, \mathrm{~N}=27)$, and less frequently for $6-10$ years $(26.7 \%, \mathrm{~N}=24)$. Only $7.8 \%(\mathrm{~N}=7)$ of the farmers suffered from low back pain for more than 20 years. In the control group, the pain lasted shorter. The biggest group indicated the period of $2-5$ years $(37.9 \%, \mathrm{~N}=11)$, while $20.7 \%(\mathrm{~N}=6)$ pointed to a period of up to 1 year and $24.1 \%(\mathrm{~N}=7)$ indicated the period of $6-10$ years. Correlations between the groups were statistically significant $(\mathrm{p}=0.04)$.

Over $40 \%$ of the examined individuals suffering from low back pain sought the help of a general practitioner, physiotherapist, chiropractor or any other specialist (farmers $-41.8 \%$, control group - 43.8\%) (Table 1). Farmers used antiphlogistic drugs or physiotherapy slightly more often (farmers - 40\%, white-collar workers - 31.3\%). In comparison to white-collar workers, farmers took painkillers (without consulting the doctor) significantly more often (farmers $-71.4 \%$, control group - 34.4\%).

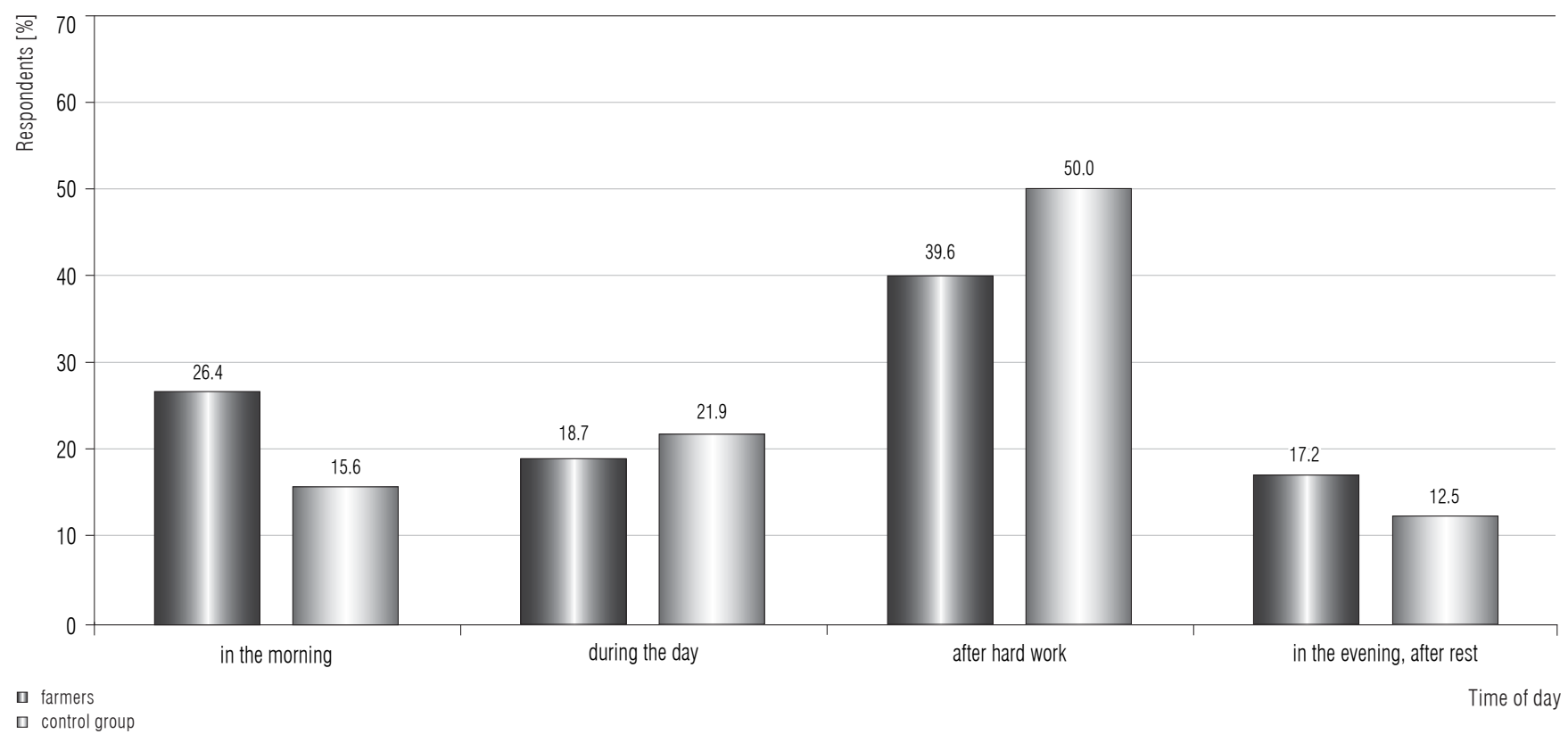

Fig. 2. Pain severity in relation to the duration of the time of day - males working $\geq 10$ years as farmers $(\mathrm{N}=106)$ vs. male white-collar workers (control group, $\mathrm{N}=50$ ) 


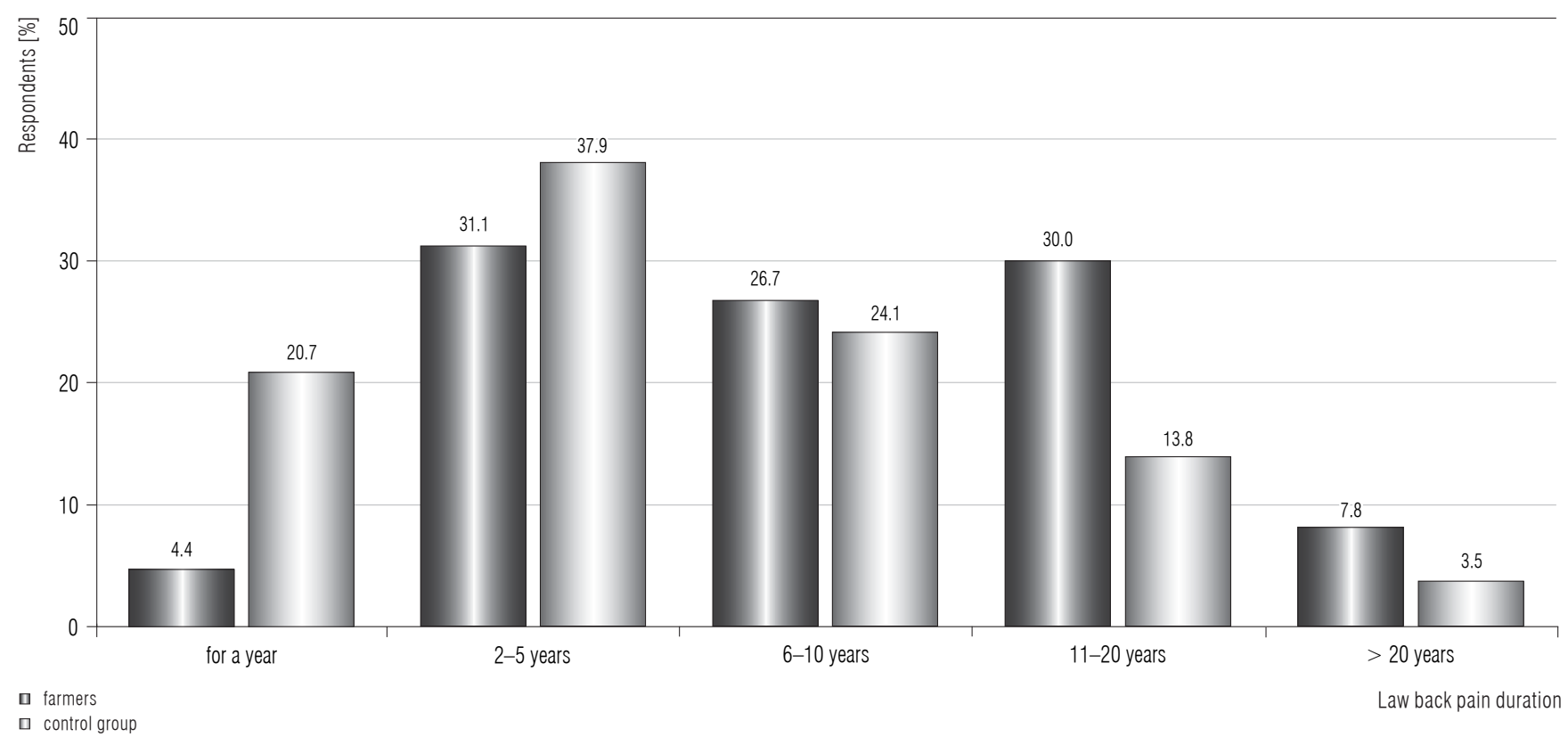

Fig. 3. Duration of the of the law back pain - males working $\geq 10$ years as farmers $(\mathrm{N}=106)$ vs. male white-collar workers (control group, $\mathrm{N}=50$ )

Respondents who experienced pain used hospital treatment very rarely (farmers - 7.7\%, control group - 12.5\%). The correlation between the groups was not statistically significant. In the control group, however, respondents reported disc herniation $(15.6 \%, \mathrm{~N}=9)$ and its treatment (60\%) more frequently than the farmers (disc herniation $-9.9 \%, \mathrm{~N}=9$; treatment $-55.6 \%$ ). The correlation between the groups was not statistically significant.

The question "Did low back pain force you to change your job?" was answered positively by $39.6 \%(\mathrm{~N}=36)$ of the farmers and $6.3 \%(\mathrm{~N}=2)$ of the respondents from the control group. The difference turned out to be statistically significant at the level of $\mathrm{p}=0.00045$.

\section{Measuring pain intensity}

on the basis of the Numeric Rating Scale (NRS) which standardizes pain assessment

In both groups pain intensity was defined on the scale from 1 to 10 .

In comparison to the control group, farmers experienced stronger low back pain and differences between the groups were statistically significant $(\mathrm{p}<0.0001)$ (Table 2). Farmers most frequently reported back pain, rating it as $5(22 \%)$ and $6(20.2 \%)$, while in the control group the reported pain was usually rated as 2 (40.6\%).

The analysis of pain intensity in relation to work experience (Table 3) showed that farmers with work experi-
Table 2. Pain intensity reported by males working $\geq 10$ years as farmers vs. male white-collar workers (control group), based on the 10-point Numeric Rating Scale (NRS) ${ }^{\mathrm{a}}$

\begin{tabular}{|c|c|c|}
\hline \multirow{2}{*}{$\begin{array}{l}\text { NRS } \\
{[p t s]}\end{array}$} & \multicolumn{2}{|c|}{$\begin{array}{l}\text { Respondents } \\
\qquad(\mathrm{N}=156) \\
{[\mathrm{n}(\%)]}\end{array}$} \\
\hline & $\begin{array}{l}\text { farmers } \\
(\mathrm{N}=106)\end{array}$ & $\begin{array}{l}\text { control group } \\
(\mathrm{N}=50)\end{array}$ \\
\hline 1 & $4(4.4)$ & $1(3.1)$ \\
\hline 2 & $4(4.4)$ & $13(40.6)$ \\
\hline 3 & $14(15.4)$ & $6(18.8)$ \\
\hline 4 & $12(13.2)$ & $6(18.8)$ \\
\hline 5 & $20(22.0)$ & $0(0.0)$ \\
\hline 6 & $17(20.2)$ & $1(3.1)$ \\
\hline 7 & $11(15.7)$ & $1(3.1)$ \\
\hline 8 & $4(4.4)$ & $4(12.5)$ \\
\hline 9 & $5(5.5)$ & $0(0.0)$ \\
\hline 10 & $0(0.0)$ & $0(0.0)$ \\
\hline
\end{tabular}

a Pearson's $\mathrm{Chi}^{2}=40.290$, degrees of freedom $(\mathrm{df})=8, \mathrm{p}<0.0001$.

ence of 10-20 years rated the intensity of their low back pain from 1 to 7 , while in the range from 5 to 7 the groups were equinumerous (17.2\% of the farmers each). No respondents chose $8-10$ on the scale. In the group of respondents with work experience of 21-30 years, the largest group rated their pain as $5(30.8 \%)$, while 
Table 3. Pain intensity reported by males working $\geq 10$ years as farmers, based on the 10-point Numeric Rating Scale (NRS), in relation to work experience

\begin{tabular}{|c|c|c|c|}
\hline \multirow[t]{2}{*}{$\begin{array}{l}\text { NRS } \\
{[\mathrm{pts}]}\end{array}$} & \multicolumn{3}{|c|}{$\begin{array}{c}\text { Farmers } \\
\text { by work experience } \\
(\mathrm{N}=106) \\
{[\mathrm{n}(\%)]}\end{array}$} \\
\hline & $10-20$ years & $21-30$ years & $>30$ years \\
\hline 1 & $1(3.5)$ & $2(5.1)$ & $1(4.4)$ \\
\hline 2 & $4(13.8)$ & $0(0.0)$ & $0(0.0)$ \\
\hline 3 & $5(17.2)$ & $6(15.4)$ & $3(13.0)$ \\
\hline 4 & $4(13.8)$ & $5(12.8)$ & $3(13.0)$ \\
\hline 5 & $5(17.2)$ & $12(30.8)$ & $3(13.0)$ \\
\hline 6 & $5(17.2)$ & $7(18.0)$ & $5(21.7)$ \\
\hline 7 & $5(17.2)$ & $4(10.3)$ & $2(8.7)$ \\
\hline 8 & $0(0.0)$ & $2(5.1)$ & $2(8.7)$ \\
\hline 9 & $0(0.0)$ & $1(2.6)$ & $4(17.4)$ \\
\hline 10 & $0(0.0)$ & $0(0.0)$ & $0(0.0)$ \\
\hline
\end{tabular}

the second largest group selected 6 (18\%). In this group, there were also farmers who selected 8 and 9 on the scale $(5.1 \%$ and $2.6 \%)$. In the group of farmers with work experience of over 30 years, the most common choice was number $6(21.7 \%)$, while numbers $3-5$ were chosen by $13 \%$ of the participants each. In this group there were also respondents who chose numbers from 7 to 9 (8 individuals each, i.e., 34.8\%). Regardless of the length of work experience, none of the respondents selected number 10 (very strong pain).

\section{Assessing disability \\ caused by low back pain based on the Oswestry Disability Index}

The research showed that approximately a half of the farmers $(49.5 \%, \mathrm{~N}=45)$ and $81.3 \%(\mathrm{~N}=26)$ of the respondents from the control group had no or minimal disability (Figure 4). Another group included $12.5 \%(\mathrm{~N}=4)$ of the white-collar workers and $39.6 \%(\mathrm{~N}=36)$ of the farmers who had moderate disability. In turn, serious disability was observed in $8.8 \%(\mathrm{~N}=8)$ of the farmers and $6.3 \%(\mathrm{~N}=2)$ of the white-collar workers, while very serious disability was noted in 2 farmers only (2.2\%). In both groups, there were no respondents with total invalidity (bedridden patients). Differences between the groups were statistically significant $(\mathrm{p}=0.016)$.

Disability caused by low back pain was also assessed with regard to work experience in years (Figure 5). Farmers most frequently reported no or minimal disability but the number of cases of such disability decreased together with an increase in work experience (from $60 \%$ in group 1 to $31.8 \%$ in group 3; statistically significant differences, $\mathrm{p}=0.01$ ).

The number of cases of serious disability rose together with an increase in work experience (from 3.3\%

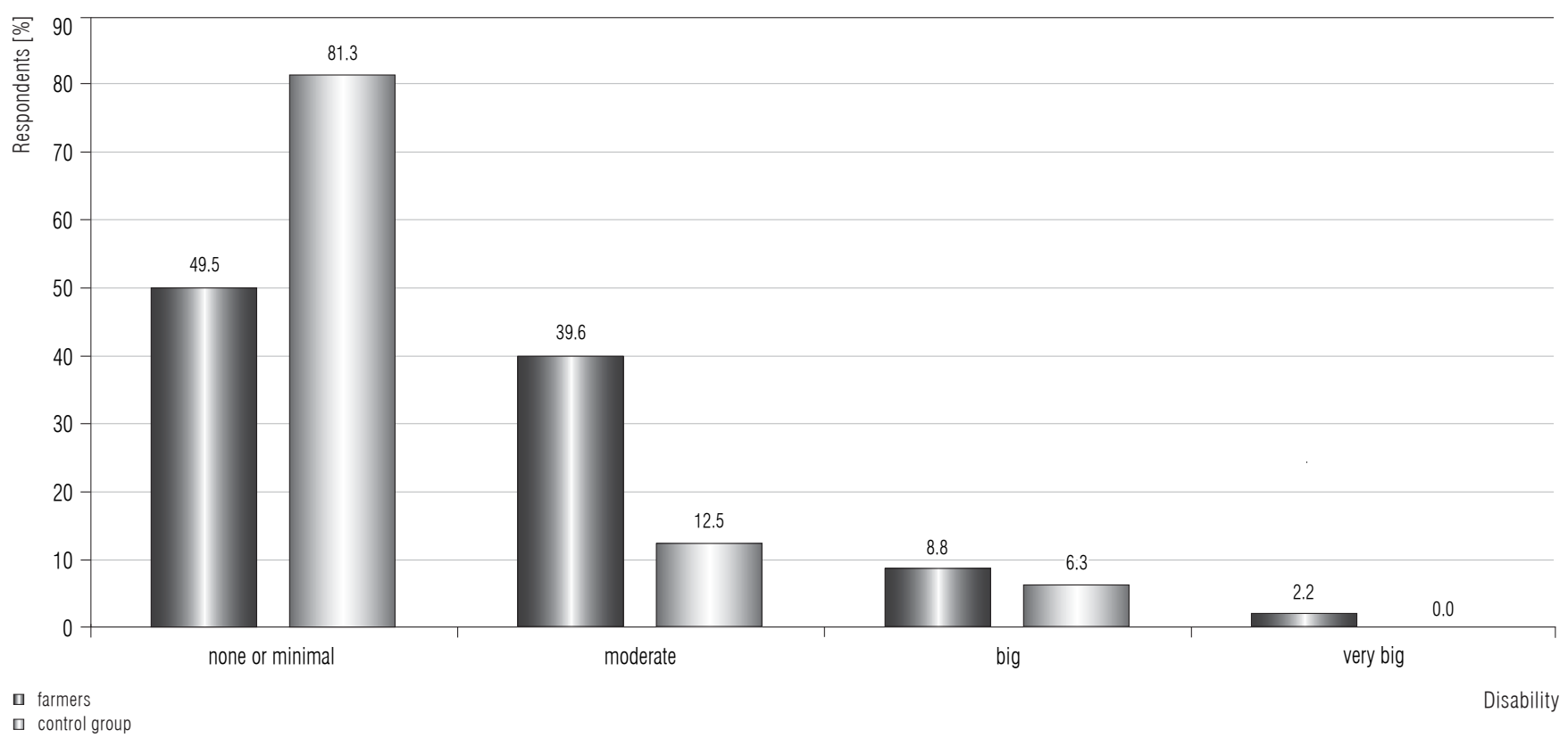

Fig. 4. Disability caused by low back pain based on the Oswestry Disability Index - males working $\geq 10$ years as farmers $(\mathrm{N}=106)$ vs. male white-collar workers (control group, $\mathrm{N}=50$ ) 


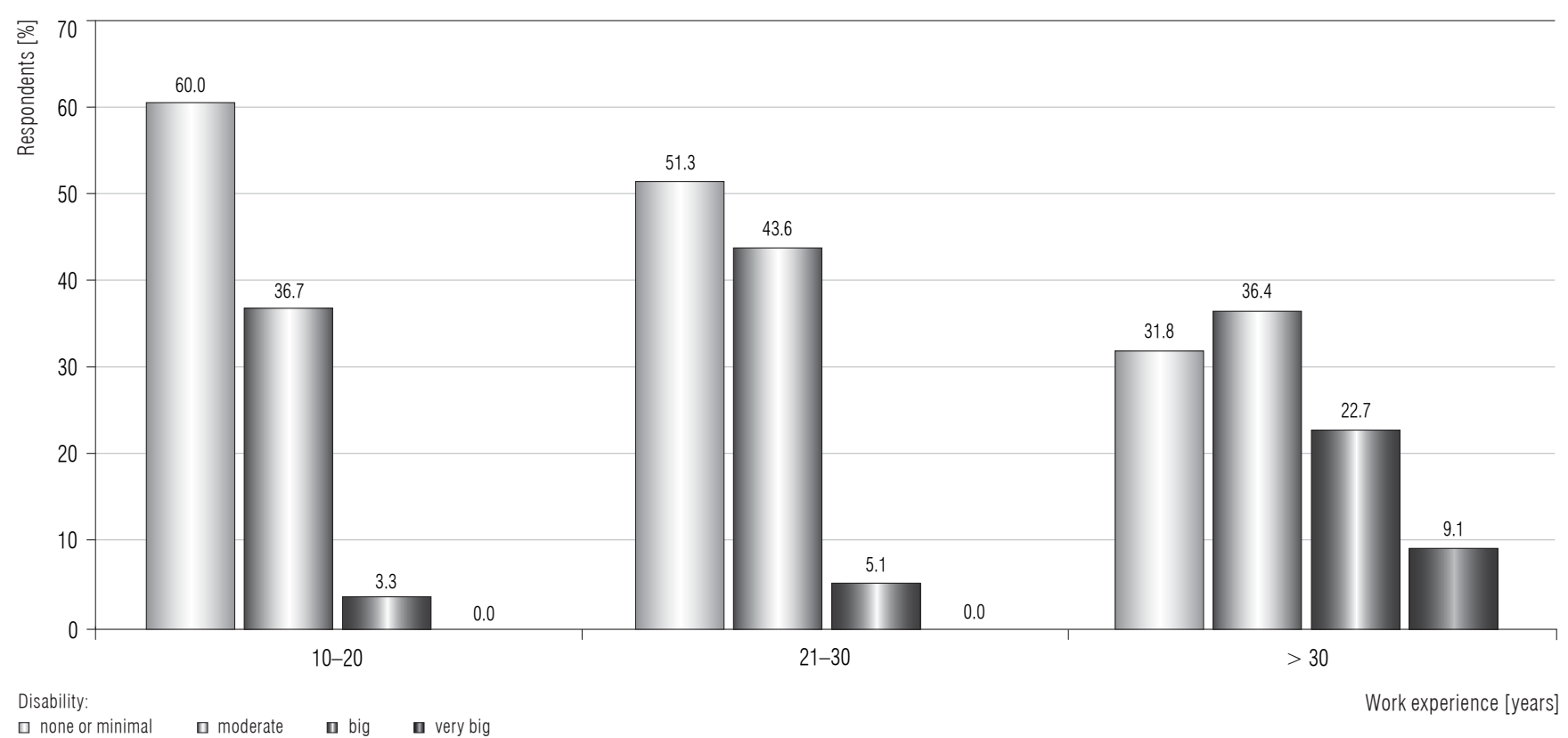

Fig. 5. Disability caused by low back pain assessed in relation to work experience - males working $\geq 10$ years as farmers $(\mathrm{N}=106)$

in group 1 to $22.7 \%$ in group 3; statistically insignificant). Severe disability occurred very rarely and was experienced by farmers with over 30-year-long work experience only (9.1\%).

The statistical analysis of the correlations between pain intensity on a $0-10$ point scale and the level of disability of farmers revealed that there existed a positive correlation between these variables, with the correlation index $r=0.53$. The value of this correlation fell within a moderate correlation range $(0.4<\mathrm{k}<0.7)$.

\section{DISCUSSION}

The research with the use of an interview questionnaire revealed that in a cohort of the farmers (106 participants) as many as $86 \%$ of them (91 individuals) experienced low back pain. In the control group only $64 \%$ of the white-collar workers reported such pain. The difference between both groups was statistically significant $(\mathrm{p}=0.002)$.

The studies carried out by various authors $[5,9,13-$ 16] revealed that low back pain was the most frequent type of pain that farmers reported, followed by neck, shoulder and upper back pain.

The research conducted by the scientists from the Institute of Agricultural Medicine in Lublin [13], which concerned initial assessment of pain in the musculoskeletal system reported by individual farmers in Poland, revealed that low back pain was experienced by $93 \%$ of all the examined farmers. In the control group (white-collar workers), 63\% of the participants reported such pain. These results were slightly higher (by $9 \%$ ) than the results of our research. This difference may be explained by the fact that the group of farmers selected for that study had longer work experience (mean: 36 years; work experience longer by 11 years). Another research showed that with an increase in work experience, back pain occurred more often [17]. However, in the control group, pain frequency was simi$\operatorname{lar}(64 \%)$.

Another study conducted in the same institute [17], which focused on low back pain among farmers exposed to whole-body vibration revealed that $94 \%$ of the farmers complained of back pain. In this case, farmers also had longer work experience (mean: 33 years; work experience longer by 8 years). However, in the control group a similar pain frequency was noted (63\%).

The farmers examined in our study defined their low back pain as constant pain or stiffness significantly more often. In addition, they felt hip pain radiating to 1 or 2 legs, experienced chronic pain and complained of acute back pain more often. In comparison to the control group, farmers experienced more frequent cases of short-term pain that was relieved. Taking into account the duration of the disorder (throughout professional life), it was concluded that mainly farmers with work experience of 11-20 years and 2-5 years suffered from pain. It is confirmed by the data from the literature [17]. 
Constant pain results in disc herniation which needs hospital treatment and long-term sick leave $[3,7,9,18]$. When strong pain occurred, farmers significantly more often took painkillers without doctor's examination (farmers $-71.4 \%$, control group - 34.4\%), which may have negative consequences in a long term.

Due to intensive pain, farmers were forced to change their job significantly more often than the participants from the control group. Farmers, especially those with working experience of 21-30 years, more often reported moderate limitations in everyday functioning.

Pain intensity was rated on the numeric scale from 1 to 10 . Farmers most often rated their pain as 5 and 6 , while in the control group pain was usually rated as 2 .

The analysis conducted with the use of the Oswestry Disability Index helped to define the level of disability among farmers. It was concluded that most frequently the farmers reported minimal disability and this tendency decreased together with an increase in work experience (statistically significant differences). The next group consisted of farmers who reported moderate disability.

The examined correlation between pain intensity rated on a numeric scale and the level of disability of farmers revealed that there existed a moderate positive correlation between these variables, with a correlation coefficient value of $r=0.53$. It was also confirmed in the study conducted by Bovenzi [19] who concluded that there was a higher risk of high-intensity pain and disability the longer the exposure time was.

Statistical analyses carried out by various authors $[5-8,10,20]$ revealed that such factors as wholebody vibration, physical work, lifting heavy loads and an uncomfortable working position (rotating and bending the trunk, static position) were positively correlated with injuries in the lumbar spine. Additionally, such factors as the number of hours of field work, type of work, work experience, age, low physical fitness and a decreased range of spine movement increase pain frequency. The same differences in prevalence of low back pain might be finding between white collar workers and other workers with physical load.

\section{CONCLUSIONS}

1. The analysis of the questionnaires revealed that individual farmers more often reported low back pain ( $\mathrm{N}=91,86 \%$ of the farmers) than white-collar workers (control group; $\mathrm{N}=32,64 \%$ ). The difference between these research groups is statistically significant $(\mathrm{p}=0.002)$.
2. Farmers defined their low back pain as constant pain, stiffness or hip pain radiating to 1 or 2 legs significantly more often than the control group.

3. Due to intensive pain, farmers were forced to change their job significantly more often than participants from the control group.

\section{REFERENCES}

1. Gałuszka R, Gałuszka G, Miziałek S. [Overload the musculoskeletal system in farmers-growers as a factor affecting the welfare]. Zdr Dobrostan. 2015;1:113-22. Polish.

2. Depa A, Drużbicki M. [Assessment of frequency of lumbalgia occurrence with relation to the character of performed work]. Przegl Med Uniw Rzeszow. 2008;1:34-41. Polish.

3. Holmberg S, Thelin A, Stiernström EL, Svärdsudd K. Low back pain comorbidity among male farmers and rural referents: A population-based study. Ann Agric Environ Med. 2005;12(2):261-8.

4. Fabunmi AA, Aba SO, Odunaiya NA. Prevalence of low back pain among peasant farmers in a rural community in South West Nigeria. Afr J Med Med Sci. 2005;34(3):259-62.

5. Meucci RD, Fassa AG, Faria NM, Fiori NS. Chronic low back pain among tobacco farmers in southern Brazil. Int J Occup Environ Health. 2015;21(1):66-73, https:// doi.org/10.1179/2049396714Y.0000000094.

6. Xiang H, Stallones L, Keefe TJ. Back pain and agricultural work among farmers: Analysis of the Colorado farm family health and hazard surveillance survey. Am J Ind Med. 1999;35(3):310-6, https://doi.org/10.1002/(SICI)10 97-0274(199903)35:3<310::AID-AJIM12>3.0.CO;2-D.

7. Park H, Sprince NL, Whitten PS, Burmeister LF, Zwerling C. Risk factors for back pain among male farmers: Analysis of Iowa Farm Family Health and Hazard Surveillance Study. Am J Ind Med. 2001;40(6):646-54, https:// doi.org/10.1002/ajim.10025.

8. Gomez MI, Hwang S, Stark AD, May JJ, Hallman EM, Pantea CI. An analysis of self-reported joint pain among New York farmers. J Agric Saf Health. 2003;9(2):143-57, https://doi.org/10.13031/2013.13004.

9. Rosecrance J, Rodgers G, Merlino L. Low back pain and musculoskeletal symptoms among Kansas farmers. Am J Ind Med. 2006;49(7):547-56, https://doi.org/10.10 02/ajim.20324.

10. Barrero LH, Hsu VH, Terwedor H, Perry MJ, Dennerlein JT, Brain JD, et al. Prevalence and physical determinants of low back pain in a rural Chinese population. Spine. 2006;31(23):2728-34, https://doi.org/10.1097/01. brs.0000244583.35982.ea. 
11. Sprince N, Park H, Zwerling C, Whitten P, Lynch C, Burmeister L, et al. Risk factors for low back injury among farmers in Iowa: A case-control study nested in the agricultural health study. J Occup Environ Hyg. 2007;4(1): 10-6, https://doi.org/10.1080/15459620601067266.

12. Kuorinka I, Jonsson B, Kilbom A, Vinterberg H, Biering-Sorensen F, Andersson G, et al. Standardised Nordic questionnaires for the analysis of musculoskeletal symptoms. Appl Ergon. 1987;18(3):233-7, https://doi.org/10. 1016/0003-6870(87)90010-X.

13. Solecki L. [Preliminary evaluation of musculoskeletal pain disorders reported by private farmers]. Med Pr. 2012; 63(3):281-93. Polish.

14. Udom C, Janwantanakul P, Kanlayanaphotporn R. The prevalence of low back pain and its associated factors in Thai rubber farmers. J Occup Health. 2016;58(6):534-42, https://doi.org/10.1539/joh.16-0044-OA.

15. Min D, Baek S, Park HW, Lee SA, Moon J, Yang JE, et al. Prevalence and characteristics of musculoskeletal pain in Korean farmers. Ann Rehabil Med. 2016;40(1):1-13, https://doi.org/10.5535/arm.2016.40.1.1.

16. Keawduangdee P, Puntumetakul R, Swangnetr M, Laohasiriwong W, Settheetham D, Yamauchi J, et al. Prev- alence of low back pain and associated factors among farmers during the rice transplanting process. J Phys Ther Sci. 2015;27(7):2239-45, https://doi.org/10.1589/ jpts.27.2239.

17. Solecki L. [Complaints of low back pain among private farmers exposed to whole body vibration]. Med Pr. 2014;65(1):55-64, https://doi.org/10.13075/mp.5893.2014. 002. Polish.

18. Kumar A, Varghese M, Mohan D, Mahajan P, Gulati P, Kale S. Effect of whole-body vibration on the low back. A study of tractor-driving farmers in north India. Spine. 1999;24(23):2506-15, https://doi.org/10.1097/00007632199912010-00013.

19. Bovenzi M. Metrics of whole-body vibration and exposure-response relationship for low back pain in professional drivers: A prospective cohort study. Int Arch Occup Environ Health. 2008;82(7):893-917, https:/doi. org/10.1007/s00420-008-0376-3.

20. Toren A, Oberg K, Lembke B, Enlund K, Rask-Andersen A. Tractor-driving hours and their relation to self-reported low back and hip symptoms. Appl Ergon. 2002;33(2):139-46, https://doi.org/10.1016/S0003-6870(01) 00061-8.

This work is available in Open Access model and licensed under a Creative Commons Attribution-NonCommercial 3.0 Poland License - http://creativecommons.org/licenses/by-nc/3.0/pl/deed.en. 